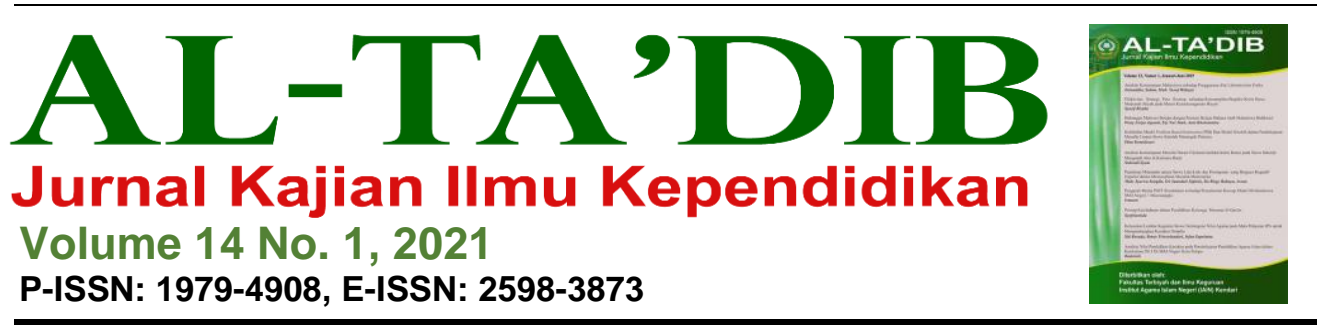

\title{
Muhammadiyah Sebagai Gerakan Pendidikan: Sejarah Eksistensi Perguruan Tinggi Muhammadiyah di Sulawesi Tenggara
}

\section{Muhammad Alifuddin ${ }^{1}$}

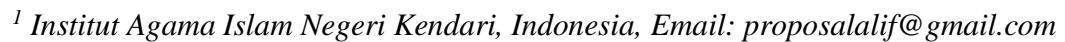

\begin{tabular}{l} 
ARTICLE INFO \\
\hline Keywords: \\
Higher education; \\
Muhammadiyah; social \\
movement theory \\
How to Cite: \\
Alifuddin, M. (2021). \\
Muhammadiyah sebagai \\
gerakan pendidikan: \\
Sejarah eksistensi \\
perguruan tinggi \\
Muhammadiyah di \\
Sulawesi Tenggara. Al- \\
Ta'dib: Jurnal Kajian Ilmu \\
Kependidikan, 14(1), 53- \\
74.
\end{tabular}

\begin{abstract}
This article presents an analytical description of the Muhammadiyah movement in the field of higher education services in Southeast Sulawesi. Data was garnered from indepth interviews, observations and documents which were analyzed through the stages of data reduction, data presentation and drawing conclusions. The results of data analysis show that there are two main factors that move Muhammadiyah to establish universities in Southeast Sulawesi. First, internal factors such as moral awareness to build civilization through education. Second, external factors such as situational "pragmatic" dimensions and the influence of geo-political dimensions. This study shows that the success of Muhammadiyah in establishing universities is closely related to the collegial collective character and the strength of Muhammadiyah's philanthropic ethos. The large network of Muhammadiyah universities makes this organ gains social legitimacy as a reliable and trusted organ in higher education governance. The capital of cultural strength and social networks by Muhammadiyah activists is mobilized intelligently through elegant framing, so that in the end this organ is not only able to establish and build but also can advance higher education in a sustainable manner.
\end{abstract}


INFORMASI ARTIKEL

Kata Kunci:

Muhammadiyah;

perguruan tinggi; teori

gerakan sosial

Cara Mensitasi:

Alifuddin, M. (2021).

Muhammadiyah sebagai

gerakan pendidikan:

Sejarah eksistensi

perguruan tinggi

Muhammadiyah di

Sulawesi Tenggara. Al-

Ta'dib: Jurnal Kajian Ilmu

Kependidikan, 14(1), 53 -

74.

\begin{abstract}
ABSTRAK
Artikel ini menyajikan deskripsi analitik tentang gerakan Muhammadiyah pada bidang layanan pendidikan tinggi di Sulawesi Tenggara. Data bersumber dari wawancara mendalam, pengamatan dan studi dokumen yang dianalisis melalui tahapan reduksi data, penyajian data dan penarikan kesimpulan. Hasil analisis data menunjukkan bahwa ada dua faktor utama yang menggerakkan Muhammadiyah mendirikan perguruan tinggi di Sulawesi Tenggara. Pertama, faktor internal yaitu kesadaran moral untuk membangun peradaban melalui jalur pendidikan. Kedua, faktor eksternal, baik yang berdimensi "pragmatis" situasional maupun pengaruh dimensi geo politik. Penelitian ini menunjukkan bahwa keberhasilan Muhammadiyah membangun perguruan tinggi terkait erat dengan karakter kolektif kolegial dan kekuatan etos filantropi Muhammadiyah. Banyaknya jaringan perguruan tinggi Muhammadiyah menjadikan organ ini mendapat legitimasi sosial sebagai organ handal dan terpercaya dalam tatakelola perguruan tinggi. Modal kekuatan budaya dan jaringan sosial oleh penggiat Muhammadiyah dimobilisasi secara cerdas melalui framing yang elegan, sehingga akhirnya organ ini tidak hanya mampu mendirikan dan membangun tetapi juga dapat memajukan perguruan tingginya secara berkelanjutan.
\end{abstract}

\section{Pendahuluan}

Pendidikan dan Muhammadiyah adalah dua hal yang merekat rapat, berjalan berkelindan, seiring melintasi lorong zaman dari segala giat warga Muhammadiyah di nusantara. Kepedulian Muhammadiyah atas pendidikan tidak dapat disanksikan, sehingga dimana ada papan nama Muhammadiyah, di situ terdapat lembaga pendidikannya (Ali, 2016). Muhammadiyah kini mengelola ribuan lembaga pendidikan, mulai dari tingkat pendidikan anak usia dini (PAUD) hingga pendidikan tinggi. Di usianya yang lebih dari satu abad, Muhammadiyah mengelola 174 perguruan tinggi yang terdiri atas 48 universitas, 5 institut dan 99 sekolah tinggi, 18 akademi, 4 politeknik. Jumlah tersebut diperkirakan akan terus bertambah, seiring dengan tuntutan dan harapan masyarakat terhadap Muhammadiyah (Huda \& Kusumawati, 2019).

Telah banyak penelitian terkait Muhammadiyah dan pendidikan yang dilakukan dilakukan, diantaranya oleh Zarro, Yunani, dan Dhita (2020) terkait Muhammadiyah sebagai gerakan Islam dan pendidikan. Demikian pula penelitian yang dilakukan oleh Subarkah (2017) tentang Muhammadiyah dan amal usaha di bidang pendidikan. Baik Zarro dkk. (2020) maupun Subarkah (2017) sepakat bahwa Muhammadiyah hadir memberikan pencerahan kepada 
umat Islam dalam menghadapi berbagai persoalan yang dialaminya, dengan memberikan pemahaman autentik dan utuh terhadap nilai-nilai ajaran Islam baik melalui jalur dakwah maupun melalui lembaga pendidikan. Historisitas Muhammadiyah sebagai gerakan pendidikan dapat dirujuk pada rumusanrumusan tujuan hadirnya Muhammadiyah mulai tahun 1921 hingga 1971 yang menggambarkan pendidikan sebagai dasar gerak dan langkahnya (Binfas, Abdullah, \& Ismail, 2014). Sementara itu, penelitian Rusydi (2017) dan Harianto (2018) tentang peran Muhammadiyah terkait konsep pendidikan, usaha-usaha di bidang pendidikan dan tokohnya menyimpulkan bahwa pendidikan bersifat integratif holistik. Hal ini didukung oleh penelitian Huda dan Kusumawati (2019) yang menelaah Muhammadiyah sebagai gerakan pendidikan. Sementara itu, penelitian yang menjadikan perguruan tinggi Muhammadiyah (PTM) sebagai fokus telaah dilakukan oleh Binangkit dan Siregar (2020) yang menyorot internasionalisasi dan reformasi perguruan tinggi dengan berbasis pada studi kasus di lembaga pendidikan Muhammadiyah. Penelitian mereka menemukan usaha jelas dari Pimpinan Pusat (PP) Muhammadiyah yang mengarahkan setiap pimpinan PTM untuk melakukan benchmarking rutin baik di dalam negeri maupun di luar negeri (Binangkit \& Siregar, 2020).

Penelitian-penelitian tersebut di atas telah mengeksplorasi kaitan erat antara Muhammadiyah dan pendidikan. Selain penelitian Binangkit dan Siregar (2020), penelitian lain yang fokus telaahnya terkait PTM masih sangat kurang dieksplorasi. Oleh karena itu, guna mengisi celah dalam fokus penelitian yang relevan, penulis tertarik menelaah fokus yang sama, namun dengan lokus dan tinjauan teori berbeda. Penelitian ini fokus pada eksistensi perguruan tinggi Muhammadiyah di Sulawesi Tenggara dengan menggunakan kajian social movement theory. Penelitian ini penting dilakukan untuk memberi data kualitatif tentang mengapa Muhammadiyah terpanggil mendirikan perguruan tinggi. Selain itu, penelitian ini diharapkan mampu memberikan gambaran tentang modal yang dimiliki Muhammadiyah dan bagaimana penggiat organ ini dapat merealisasikan PTM di Sulawesi Tenggara.

Selain sebagai gerakan dakwah, Muhammadiyah juga merupakan gerakan pendidikan (Harianto, 2018; Huda \& Kusumawati, 2019). Kemampuan Muhammadiyah mengejawantahkan gerakan pendidikannya di Nusantara secara mandiri dan berkelanjutan dapat ditelaah melalui pendekatan social movement theory. Wiktorowicz (2006) menyebutkan bahwa ada tiga hal yang sangat menentukan dalam sebuah gerakan sosial, yaitu: political opportunity spaces/structure (ruang kesempatan politik), resource mobilization (mobilisasi sumber daya), dan social framing (pembingkaian sosial). Political opportunity spaces/structure (PAS) adalah salah satu variabel yang memberi penjelasan tentang relasi yang terjadi antar perubahan 
dalam struktur dan sistem politik dengan upaya mobilisasi dalam suatu gerakan (Benford \& Snow, 2000). Eisinger (2000) menyebut political opportunity spaces sebagai ruang multidimensi yang tidak hanya dapat memberi kesempatan bagi tumbuh kembang gerakan sosial dalam satu masa, tetapi juga dapat menghambat berkembangnya suatu gerakan sosial. Kondisi sebuah lingkungan yang iklim politiknya kondusif akan membuka kesempatan lebar bagi tumbuhnya gerakan sosial, sedangkan situasi lingkungan dengan iklim politik tertutup akan mempersempit atau bahkan menutup ruang tumbuh kembang gerakan sosial (Opp, 2009; Snow, Soule, \& Kriesi, 2004). Wiktorowicz (2006) menegaskan resource mobilization theory tidak kalah penting karena disinilah gerakan sosial diaktualkan. Ketidakpuasan terhadap kondisi yang ada tidak berarti apa-apa tanpa adanya sekelompok orang yang mau melakukan kegiatan mobilisasi yang bersandar pada sumber daya yang ada. Berikutnya adalah social framing (Wiktorowicz, 2006) yang menjadi kerangka interpretasi yang memungkinkan orang untuk menempatkan, memahami, mengidentifikasi dan menamai peristiwa-peristiwa yang terjadi dalam kehidupan sekitar mereka maupun dunia secara keseluruhan. Framing, menurut Snow dkk. (2004), berperan membantu orang menyarikan peristiwa dan kejadian menjadi pengalaman bermakna kemudian mengorganisasi pengalaman tersebut dan memberi panduan untuk bertindak.

\section{Metode Penelitian}

Penelitian ini bersifat deskriptif analitik dengan menggunakan data-data kualitatif. Seluruh data dalam penelitian ini diperoleh melalui serangkaian wawancara mendalam kepada sejumlah informan yang terdiri atas tokoh dan simpatisan Muhammadiyah, serta semua pihak yang berkaitan dengan fokus penelitian. Wawancara dilakukan secara langsung guna mengungkap data yang berkaitan dengan masalah yang diteliti. Wawancara dilakukan secara tak berstandar (unstandardized interview), tidak berstruktur (unstructured interview) tetapi terfokus (focus interview) (Koentjaraningrat, 2019). Selain wawancara, data diperoleh melalui pengamatan dan studi atas sejumlah dokumen. Data-data yang terkumpul kemudian dianalisis berdasarkan alur atau struktur metode Miles, Huberman, dan Saldana (2014), yaitu reduksi data (data reduction), penyajian data (data display), dan penarikan kesimpulan/verifikasi (conclusion drawing).

\section{Hasil dan Pembahasan}

\subsection{Motif dan Daya Dukung Pendirian PTM di Sulawesi Tenggara}

Ada dua hal substansial yang dapat menjelaskan mengapa Muhammadiyah terpanggil mendirikan dan memberi layanan pendidikan tinggi bagi masyarakat Sulawesi Tenggara. Pertama, adanya dorongan visi dan misi 
keMuhammadiyahan. Hal ini dapat dikategorikan sebagai faktor internal yang bersifat moral ideologis. Kedua, adanya faktor eksternal yang mengacu pada respon Muhammadiyah atas realitas sosial.

\section{Faktor Internal}

Peacock (2017) menjelaskan bahwa pada tahun 1939, Muhammadiyah sudah mendirikan 1.744 sekolah dari segala tingkatan, dan kini jumlah tersebut terus bertambah. Data tersebut menggambarkan sebuah realitas betapa organ ini sedari awal memiliki perhatian tinggi terhadap pendidikan, dan perhatian tersebut terus berkelanjutan mengiringi zaman dan menembus batas wilayah dan budaya. Jika awal berdirinya organ ini dipandang sebagai representasi Islam perkotaan, kini pandangan tersebut menjadi tidak relevan (Subarkah, 2017). Amal usaha Muhammadiyah kini tidak hanya berdiri di pedesaan dan wilayah pesisir dengan penduduk mayoritas muslim. Fakta empiris menunjukkan bahwa banyak lembaga pendidikan Muhammadiyah berdiri di pedesaan/pedalaman, bahkan melayani komunitas non muslim seperti di Papua, Nusa Tenggara Timur dan Maluku. Menurut Mu'ti (2019), kehadiran Muhammadiyah kadang tidak populer dan menggema karena etos gerakannya sedikit bicara banyak bekerja, namun kerja keras, pengorbanan dan kiprah nyata Muhammadiyah sangat besar dalam mencerdaskan dan memajukan bangsa di seluruh persada negeri (Mu'ti, 2019).

Sinyalemen Mu'ti (2019) dalam konteks Sulawesi Tenggara setidaknya tergambar pada kemampuan elemen Muhammadiyah membangun dua perguruan tinggi "besar" yaitu Universitas Muhammadiyah Buton (UM Buton) dan Universitas Muhammadiyah Kendari (UMK). Menariknya, dua lembaga tersebut hadir dalam waktu hampir bersamaan, yaitu diawal tahun 2000 dan 2001. UM Buton dan UMK adalah fakta empiris untuk menunjukkan betapa etos kerja keras dibalut dengan semangat pengabdian komunitas Muhammadiyah mengejawantah dan terus bergerak mengikuti irama zaman. Data sejarah menunjukkan bahwa terdapat sejumlah sosok penting dibalik pendirian UM Buton dan UMK, seperti Subair, H. Edi Agus Salim, Syarifuddin Bone dan Sahir Baso di UM Buton. Menurut Zubair melalui wawancara yang dilakukan, selain empat nama tersebut, yang juga patut disebut sebagai inisiator dan telah bekerja keras adalah Abdul Rifai, A. Gani Ali, Mahmud Bunarfa, Nuki Basir, Abdul Muis, dan H. Muchlis. Sementara itu, di Kendari ada sosok Abdullah Alhadza yang diamanahi oleh Pimpinan Muhammadiyah untuk bertindak sebagai ketua tim. Abdullah Alhadza mengungkap dalam wawancara langsung dengan beliau bahwa Ahmad Aldjufri, A. Muin Ghazali, Zuhdi Mulkian, Syamsu Alam dan Nio Lassang yang adalah sosok-sosok juga bergerak simultan mewujudkan UMK. Selain dari kalangan senior, hasil wawancara dengan Syukur terungkap bahwa dari kalangan muda ada Kamiluddin Kandacong, Sainudin, Muhammad Syukur, 
Kamarudin, La Adi, Ahmad Syaiful Putra, Darman, Rasmudin dan Muammar, sebagai eksponen penggerak lapangan.

Baik Abdullah maupun Zubair dan kawan-kawan yang berperan sebagai sutradara dari berdirinya kedua perguruan tinggi tersebut adalah kader Muhammadiyah yang sejak mula keberadaannya di daerah ini telah berkhidmat dan bergelut dengan dunia pendidikan Muhammadiyah. Mengawali kehadirannya di Buton, Zubair mengungkapkan bahwa pada tahun 1986 ia mendirikan sekolah Muhammadiyah di Bau-Bau. Sementara itu, Abdullah mengawali keberadaannya di Kendari sebagai kepala sekolah SMEA Muhammadiyah. Lalu, pada tahun 1999, Abdullah diserahi amanah oleh Pimpinan Wilayah untuk menginisiasi pendirian UMK. Menurutnya, amanat tersebut merupakan tantangan yang niscaya direalisasikan. Lebih lanjut Abdullah menyebutkan bahwa inisiasi pendirian PTM di Sulawesi Tenggara merupakan panggilan moral mengingat kondisi dari realitas sosial masyarakat Indonesia di era Orde Baru menunjukkan maraknya praktek KKN (kolusi, korupsi dan nepotisme). Fenomena budaya tersebut dapat diminimalisasi dengan gerakan dakwah melalui jalur pendidikan. Abdullah mengakui bahwa atas dasar perspektif tersebut maka Muhammadiyah bergerak mendirikan perguruan tinggi guna memberi layanan pendidikan dengan tujuan meningkatkan kapasitas intelektual dan integritas moral.

Penjelasan historis di atas menunjukkan fakta kuatnya kesadaran penggiat Muhammadiyah membangun peradaban melalui jalur pendidikan (Zarro dkk., 2020). Kesadaran tersebut diikat oleh bangun theology al-ma'un, yaitu suatu perspektif keberagamaan berbasis pemberdayaan dan pembebasan. Internalisasi doktrin theology al-ma'un dalam kultur penggiat Muhammadiyah adalah salah satu jawaban atas kemampuan organ ini membangun beragam amal usaha sosial di tengah masyarakat (Mu'ti, 2019). Hal lainnya yang turut memperkuat etos kerja penggiat Muhammadiyah dalam mewujudkan amal usaha adalah semangat berfastabiqul khairat, yang meniscayakan pada setiap anggota Muhammadiyah untuk selalu terlibat aktif membangun, memberdayakan serta membebaskan dalam suasana sosial budaya yang kompetitif.

Atas dasar semangat membangun kebaikan untuk sesama maka elemen Muhammadiyah seolah tanpa henti berpikir dan bertindak mengedepankan kepentingan orang banyak dengan membangun amal usaha pendidikan (Harianto, 2018). Realitas inilah yang ditunjukkan oleh elemen Muhammadiyah di Sulawesi Tenggara sehingga mampu membangun UM Buton dan UMK sebagai monumen akal budi. Wujud universitas Muhammadiyah di Sulawesi Tenggara, menurut peneliti, merupakan indikator kuat atas hubungan positif antara semangat moral/militansi berorganisasi dengan motivasi membangun. Integrasi etos fastabiqul khairat kedalam doktrin theology al-ma'un, menurut penulis, menjadi akar penggerak 
kreatifitas dari komunitas Muhammadiyah di Buton dan Kendari untuk tampil memberikan layanan pendidikan tinggi bagi masyarakat di Sulawesi Tenggara.

\section{Faktor Eksternal}

Selain termotivasi atau bersumber dari visi dan doktrin ideologi organisasi yang sudah terinternalisasi, gerak Muhammadiyah dalam memberi layanan pendidikan tinggi di Sulawesi Tenggara juga ditunjang oleh faktor eksternal. Hasil analisis data dalam penelitian ini menunjukkan dua hal yang dapat dianggap sebagai faktor eksternal penyebab didirikannya perguruan tinggi Muhammadiyah, yaitu dimensi pragmatis situasional dan dimensi geo politik.

\section{Dimensi Pragmatis Situasional}

Pada akhir 1990-an hingga tahun 2000-an awal, pemerintah memberi ruang dan peluang besar bagi pengangkatan tenaga pendidik, khususnya untuk tingkat sekolah dasar. Dalam upaya memenuhi kebutuhan ketersediaan tenaga pendidik tersebut, pemerintah kemudian mendirikan sejumlah program studi Pendidikan Guru Sekolah Dasar (PGSD) di beberapa perguruan tinggi negeri. Realitas tersebut memantik para lulusan SLTA berebut kesempatan untuk melanjutkan pendidikan pada program studi tersebut. Akibat banyaknya peminat, perguruan tinggi negeri, khususnya di Sulawesi Tenggara tidak dapat menampung harapan sebagian masyarakat.

Para pegiat Muhammadiyah Buton lalu mencoba memfasilitasi peluang tersebut. Zubair mengungkapkan bahwa salah satu faktor pendukung atau latar belakang sehingga elemen sosial di Buton ikut mendukung berdirinya UM Buton, selain fakta minimnya perguruan tinggi untuk menampung lulusan SLTA, juga bertepatan dengan dibukanya peluang pengangkatan guru oleh pemerintah bagi alumni dan/atau sarjana PGSD. Kondisi tersebut menyebabkan minat alumni SLTA yang mencoba keberuntungan masa depan dengan mendaftarkan diri pada prodi PGSD membludak. Akan tetapi, realitas daya tampung perguruan tinggi di Sulawesi Tenggara untuk program studi terkait sangat terbatas. Implikasinya, banyak pendaftar tidak memperoleh kesempatan melanjutkan pendidikan pada prodi tersebut. Peluang tersebut kemudian ditangkap oleh Zubair sebagai kesempatan untuk menyediakan layanan pendidikan tinggi di Buton, dengan membuka program studi PGSD.

Sementara itu, di Kendari, gerak pendirian PTM tidak dapat dilepaskan dari latar atau kondisi obyektif situasi domestik Sulawesi Tenggara. Hasil pengamatan dan evaluasi elemen Muhammadiyah menunjukkan bahwa sistem tatakelola kelembagaan yang ditunjukkan oleh sebagian perguruan tinggi swasta masih jauh dari asas tatakelola yang profesional. Realitas ini memecut para profesional Muhammadiyah di bidang pendidikan untuk menawarkan 
layanan jasa pendidikan tinggi yang bersifat out of the box pada masa itu. Abdullah menjelaskan bahwa Universitas Muhammadiyah Kendari misalnya muncul dengan menawarkan konsep LEMOCEN (Learning Motivation Centre) sebagai pusat pengembangan strategi belajar terpadu dengan perpustakaan. Untuk memenuhi aspek kecerdasan spiritual para mahasiswa, UMK menawarkan konsep CATUR DARMA (penelitian, pendidikan, pengabdian dan Al-Islam Kemuhammadiyahan). Konsep yang disebut terakhir merupakan upaya Muhammadiyah mengintegrasikan antara nilainilai saintific dengan religiusitas. Meski demikian, Muhammadiyah juga tidak dapat menghindari aspek pragmatis dari tuntutan masyarakat, sehingga diawal mula berdirinya UMK juga menawarkan program Guru Taman Kanak-Kanak (PGTK).

\section{Dimensi Geo Politik}

Reformasi politik di penghujung akhir 1999, yang ditandai dengan runtuhnya kekuasaan Orde Baru di bawah kekuasaan Soeharto, membuka harapan sejumlah elemen sosial untuk dapat bergerak lebih maju dan berkompetisi secara sehat di ruang publik. Tampaknya, celah kesempatan ini terlihat jelas oleh elemen Muhammadiyah sehingga mendorong elemen persyarikatan di Buton dan Kendari menjemput kesempatan tersebut dengan unjuk kreativitas di bidang layanan pendidikan tinggi. Perubahan sejumlah regulasi dan terbukanya kesempatan berekspresi pada masa reformasi memberi angin segar bagi elemen Muhammadiyah di Sulawesi Tenggara mewujudkan niat dan harapan mereka untuk mendirikan PTM guna memberi layanan bagi sejumlah masyarakat di wilayah ini.

Untuk mewujudkan cita-cita tersebut, sejumlah kader muda Muhammadiyah di bawah manajemen Abdullah, Zubair dan kawan-kawan bergerak simultan berkejaran dengan waktu membangun rencana pendirian perguruan tinggi dan menindak lanjutinya secara cepat. Abdullah dan Zubair mengakui bahwa tidak mudah menjalankan roda perencanaan dengan sumber daya manusia dan finansial terbatas untuk membangun sebuah bangunan monumental. Akan tetapi, tekad kuat mereka yang dipadu dengan pengorbanan mewujudkan berdirinya dua perguruan tinggi dalam kurun waktu yang tidak terlalu lama. Diawali dengan berdirinya Universitas Muhammadiyah Buton pada tahun 2000, lalu kemudian disusul Universitas Muhammadiyah Kendari pada tahun 2001, persyarikatan yang didirikan oleh KH. Ahmad Dahlan ini tampil ke permukaan untuk mengasah, mengasuh dan menghias peradaban Bumi Anoa.

Sekalipun masa reformasi memberi peluang besar bagi setiap elemen sosial untuk mengekspresikan kreatifitasnya, namun bukan berarti pendirian kedua PTM tersebut dilakukan semudah membalikkan kedua telapak tangan. Problem mendasar yang niscaya terpenuhi dalam pendirian perguruan tinggi, 
selain kepemilikan lahan sebagai tempat bangunan, juga syarat sumber daya manusia serta jaminan finansial yang tidak sedikit jumlahnya. Bagi Muhammadiyah, problem kepemilikan lahan dan tempat perkuliahan dapat dikatakan tidak menjadi penghalang signifikan mengingat tapak jejak sejarah Muhammadiyah baik di Kendari maupun Buton mewariskan sejumlah amal usaha pendidikan. Masalah pelik terletak pada ketersedian sumber daya manusia dan jaminan finansial atau semacam bank garansi. Dalam konteks dua hal inilah, Abdullah mengakui, akan tampak kecerdesan emosional dan spiritual komunitas Muhammadiyah.

Di Kendari, upaya memenuhi ketersediaan tenaga pendidik dan kependidikan nyaris tidak sesukar di Buton mengingat Kendari sebagai ibukota provinsi. Secara logika, daerah ini tempat berkumpulnya sejumlah sumber daya manusia berkualitas sebagai perwakilan dari sejumlah wilayah di Sulawesi Tenggara. Banyak kader struktural maupun kultural yang berdomisili di tempat ini berprofesi sebagai dosen maupun pegawai dengan kualifikasi pendidikan S2. Hal ini berbeda dengan realitas Buton. Dalam konteks inilah menarik ditelaah bagaimana komunitas Muhammadiyah Buton memenuhi ketersedian dosen pada waktu itu sebagai syarat penting dalam pendirian dan jalannya roda lembaga. Dalam hal ini, Zubair tampil sebagai inisiator UM Buton yang dengan keberaniannya bertindak mengumumkan melalui media tentang lowongan penerimaan bagi tenaga pendidik untuk berkarir sebagai seorang dosen di tanah Buton. Pengumuman tersebut disambut dalam waktu singkat sehingga terjaring 12 orang dosen untuk ditempatkan di UM Buton. Keberanian Zubair sebenarnya tidak ditopang dengan kesiapan membiaya hidup sejumlah dosen, sehingga untuk membiayai hidup 12 orang dosen yang telah direkrut dibebankan kepada sejumlah anggota pimpinan daerah Muhammadiyah Buton. Realitas ini hanya akan terjadi atau dapat terjadi pada sebuah lingkungan organisasi yang memiliki model kerja kolektif kolegial seperti dalam Muhammadiyah. Zubair mengungkapkan bahwa hal ini sekaligus menunjukkan bahwa karakter alma'un sebagai salah satu doktrin organisasi mengejawantah dalam tradisi Muhammadiyah Buton, setidaknya pada awal mula mendirikan UM Buton.

Di Kendari, menurut Abdullah, ketercukupan jaminan finansial bagi pendirian perguruan tinggi Muhammadiyah dipenuhi oleh Ahmad Aldjufri dan Abdullah. Sedangkan untuk membangun infrastruktur digagas model pengumpulan dana dalam bentuk saham. Ide ini menjadi sangat beralasan guna memantik semangat para anggota Muhammadiyah mengumpulkan dana talangan sebagai salah satu persyaratan pendirian perguruan tinggi. Selain itu, untuk mencukupi dana pembangunan gedung maka Abdullah dan Nio Lassang menjaminkan sertifikat mereka ke Bank Muamalat Indonesia. Sedangkan di Buton, dana talangan diperoleh dari urunan warga Muhammadiyah setempat. Dari kedua model pengumpulan dana tersebut, sungguhpun tampak berbeda 
di permukaan, namun hakikatnya berbasis filantropi. Pengumpulan dana model Abdullah kemudian menjadi saham sejarah dan diwakafkan kepada Muhammadiyah. Gambaran model pengumpulan dana tersbut menunjukkan bahwa jiwa filantropi adalah bakat bawaan Muhammadiyah (Amar, 2017; Arfandi, 2016). Jiwa tersebut menguat melalui doktrin theologi al-ma'un (Mu'ti, 2019).

Dalam perjalanannya, kedua universitas tersebut dapat dinyatakan sebagai dua perguruan tinggi swasta papan atas di Sulawesi Tenggara. Keduanya merupakan tempat sebagian masyarakat menggantungkan harapan masa depan anaknya untuk dididik menjadi sarjana. Menariknya, sekalipun kedua universitas tersebut tidak berada pada wilayah tujuan pendidikan seperti Makassar atau Jawa, namun input mahasiswanya tidak hanya datang dari wilayah Sulawesi Tenggara, tetapi juga dari provinsi lainnya seperti Papua, Maluku, Maluku Utara, Sulawesi Tengah, bahkan Nusa Tenggara Timur.

\subsection{Landasan Gerak dan Modal Pendirian UM Buton dan UMK}

Berdirinya UM Buton dan UMK pada awal tahun 2000-an menjadikan Muhammadiyah tercatat sebagai organisasi sosial Islam pertama di Sulawesi Tenggara yang memiliki perguruan tinggi. Realitas tersebut merupakan indikator bagi progresivitas langkah Muhammadiyah di bidang pendidikan, melampaui elemen sosial Islam lainnya. Pandangan tersebut bukan tanpa alasan, mengingat dari sekian banyak ormas Islam di wilayah ini, hanya Muhammadiyah yang berani tampil bergerak mendirikan perguruan tinggi. Dipelopori oleh Zubair dkk. di Buton dan Abdullah Alhadza di Kendari, komunitas Muhammadiyah bergotong royong mendorong lahirnya perguruan tinggi sebagai penanda eksplisit bahwa organ ini mewarisi spirit berkemajuan (Ali, 2017). Hal tersebut menunjukkan bahwa pendirian UM Buton dan UMK terkait erat dengan kemampuan elemen Muhammadiyah dalam melihat dan memanfaatkan peluang.

Merujuk pada data tahun pendirian kedua PTM tersebut, UM Buton berdiri satu tahun lebih awal dari UMK. Fakta ini menunjukkan bahwa spirit berkemajuan di lingkungan Muhammadiyah tidak terikat oleh titik epicentrum organisasi. Bagi orang Muhammadiyah, titik epicentrum bukan penanda absolut dari gambaran aktivitas gerak organisasi. Sekretariat sebagai titik epicentrum dalam Muhammadiyah tidak lebih sebagai wadah untuk menyatukan rencana dan titik kordinasi dalam mengimplementasikan suatu kegiatan. Upaya memproduksi amal usaha kebajikan dalam Muhammadiyah tidak sepenuhnya bergantung pada titik epicentrum organisasi. Hal ini sejalan dengan jargon fastabiqul khairat sebagai kultur identitas Muhammadiyah (Nashir, 2015). Bukti tesis di atas terlihat pada sejarah pendirian dua PTM di Sulawesi Tenggara. Meskipun Kendari merupakan ibukota Propinsi Sulawesi Tenggara dan sekretariat Pimpinan Wilayah Muhammadiyah Sulawesi 
Tenggara berkedudukan di Kendari, namun tapak jejak sejarah dari PTM di wilayah ini justru bermula dari Buton. Hal ini menunjukkan bahwa kaderkader Muhammadiyah sesungguhnya adalah sekumpulan sumber daya kreatif, progresif dan independen. Kerja untuk membangun dan berlomba dalam kebaikan ditunjukkan secara nyata oleh komunitas Muhammadiyah tanpa terikat oleh masa dan tempat (Mu'ti, 2019; Nashir, 2015).

Realitas sejarah sebagaimana yang digambarkan di atas menjadi pertanda kuatnya spirit budaya fastabiqul khairat. Dalam Muhammadiyah, inisiasi sebuah gagasan besar tidak tergantung pada titik wilayah dimana elit struktural Muhammadiyah berada. Tetapi mereka akan selalu bergerak, berinisiatif dalam kebaikan guna berkhikmat untuk bangsa dan agama kapan dan dimanapun mereka berada, tanpa mengenal lelah. Segala peluang disikapi secara arif dan penuh kreativitas dalam rangka menebarkan kebaikan bagi sesama. Nilai fastabiqul khairat terinternalisasi dalam kultur identitas Muhammadiyah. Dalam ruang Muhammadiyah, nilai tersebut memiliki kekhasan karena nilai tersebut bersifat kolektif kolegial (Nashir, 2015).

Integrasi nilai fastabiqul khairat dalam ruang kolektif kolegial ini yang menjadi penjelas mengapa Muhammadiyah mampu mendirikan amal usaha di berbagai tempat, kendatipun para anggotanya umumnya berasal dari kelompok sosial ekonomi menengah ke bawah. Bahkan ketika organ ini berada dalam situasi dan kondisi politik represif, mereka tetap mampu eksis dan menerobos masa. Infrastruktur Muhammadiyah yang kasat pandang di Nusantara menkonfirmasi betapa jiwa kolektif kolegial dalam berfastabiqul khairat menyata dan mengakar dalam kultur Muhammadiyah. Jika saja kultur itu hidup di atas akar yang rapuh maka mustahil mengharapkan terwujudnya infrastruktur dengan inisiatif dana mandiri, namun kepemilikannya bukan atas nama mereka yang membangun dan meneteskan dana serta keringatnya (Usman, 2019). Fenomena ini sejatinya tidak logis jika ditakar dengan hukum kebiasaan dalam berkarya, yaitu setiap rencana, jerih payah dan hasil kerja yang diukir seseorang dimiliki oleh individu dan atau mereka yang telah menggagas dan mengusahakannya. Konsep tersebut tidak familiar dalam Muhammadiyah, tidak bagi komunitas yang melebur diri dalam ruang sosial dan budaya Muhammadiyah yang niscaya menyiapkan diri melakukan lompatan logika kehidupan (Nashir, 2015).

Tradisi indah tersebut dapat terus terwarisi dan mengejawantah dalam kultur Muhammadiyah karena ia terbalut oleh keyakinan tauhid. Dengan kata lain, gerak aktivitas untuk membangun keadaban publik dalam Muhammadiyah merupakan tindakan sosial berbasis tauhid. Tindakan ini adalah suatu aktivitas membangun kebajikan kepada sesama dan untuk kepentingan bersama yang didasarkan atas suatu keyakinan bahwa tindakan amal saleh kolektif adalah bagian dari keimanan yang sangat mendasar (Nashir, 2015). Dalam Muhammadiyah, tindakan sosial berbasis tauhid 
disebut dengan istilah theology al-ma'un, yaitu konstruksi kehidupan religius yang menempatkan kepedulian sebagai bagian tak terpisahkan dengan iman. Dalam perspektif theology al-ma'un, kepedulian terhadap sesama akan sangat menentukan status seseorang di hadapan Allah (Mu'ti, 2019). Artinya, segala kebaikan yang dihasilkan dalam rangka berfastabiqul khairat hasil akhirnya bukan untuk kepemilikan pribadi tetapi diserahkan sebagai "milik" Tuhan. Hal ini yang menjadi sebab bahwa dalam sejarah tidak seorangpun pimpinan Muhammadiyah yang membangun sekolah/madrasah, pesantren, panti asuhan, rumah sakit, perguruan tinggi kemudian menjadikan apa yang dirintisnya sebagai miliknya atau diwariskan kepada keluarga (Usman, 2019). Dalam kasus pendirian UM Buton dan UMK, penggagas sebagai subyek pembangun pun bukan pemilik PTM tersebut, sekalipun boleh jadi mereka telah berkorban harta, waktu dan tenaga. Inilah perbedaan signifikan landasan gerak Muhammadiyah dengan kebanyakan organisasi dan badan usaha, sekaligus merupakan keunikannya (Mu'ti, 2019).

UM Buton dan UMK sebagai salah satu penanda kepedulian Muhammadiyah untuk mencerdaskan kehidupan bangsa, tidak lahir dan besar tiba-tiba. Wujud eksistensi kedua PTM yang tampak saat ini merupakan hasil dari perjuangan panjang dengan beragam dinamika. Tidak sedikit tantangan dan rintangan dalam proses mewujudkan kedua lembaga tersebut. Jika kini kedua institusi tersebut terlihat kokoh menelusuri alur jaman maka dipastikan terkait erat dengan etos dan militansi para pendiri dan penggeraknya. Menurut penulis, setidaknya terdapat dua modal dasar sebagai penopang kemampuan elemen Muhammadiyah dalam bergerak mendirikan, merealisasikan dan mempertahankan keberlanjutan UM Buton dan UMK. Kedua modal tersebut adalah modal budaya dan modal sosial.

\section{Modal Budaya}

Perjalanan panjang Muhammadiyah dalam ruang sejarah Indonesia, mustahil berkelanjutan jika tidak diikat oleh satu sistem nilai (values) (Nashir, 2015). Nilai-nilai tersebut hidup dan memberi pengaruh dalam sistem cara berpikir orang Muhammadiyah sehingga membentuk suatu kesadaran untuk melakukan satu tindakan bersama. Salah satu nilai yang melekat dan terpelihara dalam kultur Muhammadiyah adalah nilai fastabiqul khairat, yaitu nilai atau kultur untuk selalu membangun dan berkompetisi secara sehat guna mewujudkan kebaikan. Nilai budaya fastabiqul khairat tumbuh dan dikuatkan dengan doktrin ideologi tauhid murni (mengesakan segala keyakinan hanya kepada Allah). Derivasi lanjutan dari konsep nilai tersebut adalah bahwa setiap anggota organisasi niscaya mendedikasikan dan mendasari segala perbuatannya semata-mata karena Allah, sehingga segala hasil kerja kreativitasnya bukan ditujukan untuk kepemilikan pribadi tetapi diwakafkan kepada umat melalui Muhammadiyah. 
Tampaknya kultur ini menjadi salah satu pondasi kuat yang menjadikan komunitas Muhammadiyah tetap eksis dan dapat bergerak maju melintasi jaman. Budaya fastabiqul khairat yang berbasis pada konsep tauhid, menjadi energi positif pada diri individu dan komunitas Muhammadiyah di Buton dan Kendari, sehingga sekalipun pada kenyataannya mereka tidak memiliki banyak modal finansial, hal tersebut tidak menghalangi mereka mewujudkan lahirnya dua PTM. Nilai budaya fastabiqul khairat telah menggerakkan komunitas Muhammadiyah untuk maju membangun melalui kekuatan budaya infaq, sadaqah dan wakaf. Wujud UM Buton dan UMK membuktikan betapa tradisi membangun amal usaha dalam Muhammadiyah tidak bergantung pada kekuatan pemodal, tetapi secara konsisten bertumpu pada sokongan dan dukungan warga persyarikatan (Latief, 2019; Subarkah, 2017).

\section{Modal Sosial}

Kekuatan lain sebagai pendorong usaha komunitas Muhammadiyah dalam membangun lembaga pendidikan tinggi di Sulawesi Tenggara adalah modal sosial, yaitu modal kepercayaan dalam konteks relasi atau hubungan sosial dengan dunia di luar mereka (Setiawan, 2019). Banyaknya jaringan layanan pendidikan Muhammadiyah di Nusantara merupakan modal dasar bagi komunitas organ ini untuk dapat bergerak maju dan leluasa (Setiawan, 2019). Ratusan amal usaha pendidikan tinggi merupakan legitimasi sosial bagi komunitas Muhammadiyah untuk mendapatkan kepercayaan dari pemerintah sebagai pemegang hak atas perizinan usaha mendirikan lembaga perguruan tinggi. Menjamurnya jaringan lembaga pendidikan Muhammadiyah di negeri ini menguatkan keyakinan pemerintah bila pendirian lembaga pendidikan Muhammadiyah tidak mungkin diragukan karena tidak akan merugikan masyarakat sebagai stakeholder. Hal ini berbeda dengan kebanyakan organisasi pendidikan dalam bentuk yayasan dengan kepemilikan pribadi. Selain adanya kepercayaan pemerintah, konsistensi gerak Muhammadiyah melintasi jaman dengan berbagai aktivitas dan layanan sosial telah menjadi jaminan dengan harga tak ternilai. Modal tersebut menjadi salah satu variabel mudahnya Muhammadiyah mendirikan perguruan tinggi (Husnaini, 2019).

\section{Pembahasan}

Pada prinsipnya, giat Muhammadiyah di bidang penyediaan layanan pendidikan bukanlah hal baru dan tiba-tiba, karena sejarah telah mencatat bahwa organ ini sejak awal mula keberadaannya telah berkhidmat untuk mencerdaskan kehidupan bangsa (Peacock, 2017). Sekalipun pendidikan merupakan bagian tak terpisahkan dari dunia Muhammadiyah, namun tidak berarti pendirian dan penyelenggaraan pendidikan oleh organ ini berjalan mulus setiap masa dan keadaan. Fakta menunjukkan bahwa sejak masa penjajahan Belanda hingga masa kemerdekaan, Muhammadiyah mendapat 
sejumlah tantangan dalam menjalankan ide-ide pendidikannya. Meski demikian, berkat pengalaman dan militansi gerak komunitas Muhammadiyah, sehingga berbagai tantangan dapat diatasi melalui negosiasi dan adaptasi.

Kajian berikut ini berusaha menganalisa bagaimana komunitas Muhammadiyah Sulawesi Tenggara menghadapi situasi sosial sebagai rintangan dalam mendirikan lembaga pendidikan tinggi. Dalam perspektif teori gerakan sosial, setidaknya ada tiga variabel yang dapat menunjukkan bagaimana sebuah aktivitas sosial yang bertujuan untuk melakukan perubahan dapat eksis dan berkesinambungan. Ketiga variabel tersebut adalah: political opportunity spaces (ruang kesempatan politik), resource mobilization (mobilisasi sumber daya), dan social framing (pembingkaian sosial) (Opp, 2009; Snow dkk., 2004).

\subsection{Reformasi sebagai Struktur Kesempatan Politik}

Reformasi politik tahun 1998 yang ditandai dengan peralihan kepemimpinan politik tahun 1999 telah memberi kesempatan luas bagi setiap elemen masyarakat untuk menuangkan kreatifitasnya dalam ruang sosial. Situasi tersebut direspon oleh elemen Muhammadiyah untuk menyalurkan bakat bawaannya sebagai organ pegiat dunia pendidikan, yaitu dengan berfastabiqul khairat mendirikan institusi pendidikan dan aktivitas sosial lainnya. Tampaknya, ruang lebar bagi setiap elemen sosial untuk berpartisipasi memajukan kehidupan bangsa dimaksimalkan secara proporsional dan profesional oleh elemen Muhammadiyah. Meskipun dalam perjuangan reformasi Muhammadiyah memiliki andil besar, namun Muhammadiyah memilih untuk tidak larut dengan euforia kebebasan yang seolah tak berbatas (Nashir, 2015). Ruang politik terbuka di era reformasi dimanfaatkan secara cerdas, arif dan elegan oleh pegiat Muhammadiyah di Sulawesi Tenggara. Bagi warga persyarikatan, reformasi sebagai penyaji kesempatan bagi semua pihak untuk berkarya tanpa harus dihantui rasa takut dimaknai sebagai tanggungjawab dan kesempatan untuk menabur benih kebaikan bagi masyarakat. Dalam konteks inilah dapat dipahami mengapa gerakan membangun PTM di Sulawesi Tenggara bisa terealisasi.

Fakta lain yang menjelaskan mengapa ruang politik reformasi dinyatakan sebagai daya dukung positif bagi lahirnya PTM di Sulawesi Tenggara adalah adanya relasi antara eksponen Muhammadiyah dengan pengendali kebijakan di tingkat pusat waktu itu. Sejarah mencatat bahwa setelah tumbangnya kekuasaan Soeharto, beberapa orang di antara kader Muhammadiyah menduduki posisi strategis, khususnya di Kementerian Pendidikan. Kenyataan tersebut tidak dapat disangkal telah memberi ruang bagi sejumlah pegiat Muhammadiyah untuk memaksimalkan kemampuan alami organisasi ini dalam menggerakkan dunia pendidikan. Fakta ini juga diakui oleh Abdullah dan Zubair ketika berupaya merealisasikan berdirinya 
UM Buton dan UMK. Meskipun demikian, Zubair mengungkapkan bahwa upaya mewujudkan cita-cita tesebut dilalui dengan penuh tantangan karena mereka harus melewati regulasi dengan sejumlah variabel menantang. Misalnya, mereka wajib menyiapkan dana pertanggungan yang dibuktikan melalui rekening dan laporan keuangan. Demikian halnya dengan kesiapan sumber daya pendidikan dan tenaga pendidik dan kependidikan.

Deskripsi di atas secara kasat mata menunjukkan bagaimana pengaruh ruang struktur politik reformasi berkontribusi positif pada sebuah gerakan sosial. Hal tersebut equivalen dengan gambaran Benford dan Snow (2000) yang menyatakan bahwa keadaan lingkungan struktur politik memberikan sebuah kesempatan tersendiri bagi gerakan sosial untuk bisa muncul sekaligus berkembang. Ruang struktur politik terbuka dalam kenyataannya memang berpengaruh signifikan atas lahirnya kesempatan bagi individu dan atau komunitas sosial untuk mengekspresikan karya dalam dunia nyata. Meski demikian, keberhasilan dalam ruang tersebut hanya mungkin diperoleh oleh kelompok yang memiliki inovasi dan kreatifitas tinggi disertai motivasi untuk memajukan negeri (Husnaini, 2019). Komunitas Muhammadiyah Sulawesi Tenggara adalah salah satu elemen sosial yang secara empirik membuktikan hal tersebut dengan bukti monumen bertuliskan UM. Buton dan Universitas Muhammadiyah Kendari.

Hal yang penting dicatat adalah bahwa niat Muhammadiyah berkontribusi dan membangun peradaban bangsa melalui jalur pendidikan tinggi dapat tercapai bukan semata-semata karena terbukanya ruang struktur politik. Dengan kata lain, realitas pola hubungan antar aktor dengan struktur politik yang bersifat open system hanya merupakan salah satu variabel (Benford \& Snow, 2000). Dengan demikian, reformasi sebagai struktur kesempatan politik yang menciptakan pola hubungan terbuka dimana aktifitas politik yang ada lebih kompetitif yang terbangun antar elit, partai politik dengan kelompok kepentingan, memberi kesempatan peluang keberhasilan yang lebih besar bagi setiap elemen sosial untuk mendedikasikan darma baktinya secara lebih nyata. Berdasarkan wawancara dengan menurut Ahmad Aldjufri, bagi Muhammadiyah, hal ini berbeda dengan keberadaannya di era awal 70-an hingga akhir 90-an, dimana pemerintah mengembangkan struktur yang bersifat close system, sehingga gerakan Muhammadiyah di wilayah ini hanya mampu merayap dalam ruang gelap dan dalam suasana senyap.

\subsection{Mobilisasi Sumber Daya}

Sumber daya adalah segala sesuatu yang memiliki nilai manfaat, bisa dikontrol dan dikuasai serta dimanfaatkan secara individu atau kolektif untuk tujuan dari visi misi organisasi. Cakupan definisi sumber daya memiliki makna luas, terdiri atas kekuatan finasial, akses terhadap media, dukungan simpatisan dari sebuah kelompok. Sumberdaya juga meliputi kepemilikan atas 
sesuatu seperti gedung, pengetahuan dan skill, termasuk nilai ideologi yang dimiliki oleh aktor (Opp, 2009). Meski cakupan pengertian makna sumber daya sangat luas, namun orientasi umum masyarakat terhadap dana atau finansial sebagai sumber daya "paling" utama. Dalam banyak kasus, seseorang ataupun suatu kelompok sangat tergantung dengan dana atau modal finansial dalam menggerakkan organ sosial. Oleh karena itu, dalam banyak kelompok sosial, dana dipandang sebagai elemen fundamental untuk mendorong laju suatu pergerakan. Sebagaimana organisasi lainnya, Muhammadiyah juga butuh dana untuk dapat melaju mengikuti irama zaman.

Pertanyaannya kemudian, apakah gerakan Muhammadiyah dalam mendirikan lembaga pendidikan tinggi terwujud dengan sebab sokongan dana dari pimpinan pusat atau pimpinan wilayah atau funding lainnya dari luar maupun dalam negeri? Kenyataannya, pembanguan dua PTM di Sulawesi Tenggara terealisasi bukan karena suplai dana dari Pimpinan Pusat Muhammadiyah. Untuk mewujudkan dua institusi tersebut dibutuhkan pembiayaan atau dana besar, namun sumbernya bukan berasal dari pimpinan institusi. Dana sebagai salah satu penggerak dalam mewujudkan keinginan mendirikan perguruan tinggi sebagaimana dimaksud bersumber dari energi filantropi komunitas Muhammadiyah di kedua tempat. Pertanyaan selanjutnya adalah bagaimana Muhammadiyah mendorong energi tersebut sehingga dapat aktif, mengingat disamping kebutuhan atas dana pembiayaan yang besar, di sisi lain diketahui komunitas Muhammadiyah umumnya bukan berasal dari kelompok mapan ekonomi?

Hasil analisis penelitian ini telah memaparkan bahwa salah satu aspek fundamental yang membuat elemen Muhammadiyah mampu bergerak dan merealisasikan rencana pendirian UM Buton dan UMK adalah kreatifitas elemen persyarikatan dalam memobilisai sumber daya internal maupun sumber daya eksternal. Secara prinsip, kepercayaan diri elemen Muhammadiyah dalam membangun amal usaha dibentuk oleh satu keyakinan bahwa pada diri sebagian besar kader persyarikatan bersemayam jiwa atau karakter filantropi. Hasil penelitian Arfandi (2016) menyebutkan bahwa filantropi identik dengan Muhammadiyah. Hal ini ditegaskan oleh hasil penelitian Amar (2017) yang menyatakan bahwa umumnya komunitas Muhammadiyah tidak terlalu tertarik pada polemik keagamaan. Muhammadiyah lebih cenderung pada kerja kemanusian, kedermawanan, cinta dan peduli pada sesama. Kuatnya citra kepedulian dalam gerakan Muhammadiyah telah mendorong warga organisasi ini membangun ribuan amal usaha untuk didedikasikan bagi masyarakat Indonesia. Menjamurnya amal usaha Muhammadiyah di seantero nusantara membuktikan bahwa sejumlah orang yang memilih untuk berada dalam barisan Muhammadiyah adalah subyek yang berkarakter filantropis (Amar, 2017; Mu'ti, 2019). Etos filantropi yang mengakar dalam identitas elemen Muhammadiyah mampu 
dimaksimalkan, sehingga sekalipun banyak kendala menghadang dalam proses pendirian kedua PTM tersebut, akhirnya dapat dilalui satu persatu.

\subsection{Sosial Framing}

Eksistensi gerakan PTM sebagai kontribusi positif dan produktif kepada masyarakat Sulawesi Tenggara selain ditunjang oleh situasi sosial politik yang kondusif, juga tidak dapat dilepaskan dari kemampuan elemen persyarikatan dalam mempromosikan dan memberi kemasan atas gagasan tersebut. Sebagai produk, kehadiran lembaga PTM di Sulawesi Tenggara mampu disosialisakan atau dipromosikan dengan cara elegan. Proses tersebut dalam teori gerakan sosial disebut framing, yaitu suatu hal yang merujuk pada fenomena aktif dan berproses dengan melibatkan agen dalam membangun realitas. Goffman menyebutkan framing sebagai skema dari intrepretasi yang memungkinkan individu, untuk memetakan, memahami dan mengindentifikasi serta memberi label atas setiap kejadian atau peristiwa dalam ranah kehidupan dan dunia secara umum (Benford \& Snow, 2000; Snow dkk., 2004).

Konstruksi citra sebuah perguruan tinggi dalam ruang sosial menjadi sangat penting karena terkait erat dengan kelanjutan eksistensi lembaga tersebut pada masa-masa berikutnya. Dalam konteks ini, setiap penyelenggara dan penyedia jasa layanan pendidikan tinggi harus melakukan proses pencitraan guna menarik simpatik dari stakeholder. Strategi tersebut juga dilakukan oleh pegiat Muhammadiyah ketika awal mula memperkenalkan dan membangun lembaga pendidikannya. Kehadiran UMK di ruang publik Sulawesi Tenggara, sebagaimana dijelaskan Abdullah, adalah untuk menjawab keinginan masyarakat bagi terselenggaranya outcome pendidikan tinggi yang tidak hanya cerdas secara intelektual tetapi juga memiliki kematangan emosional dan spiritual. Dalam hal ini, elemen Muhammadiyah menawarkan konsep pendidikan yang mengintegrasikan antara sains dan nilainilai moralitas keagamaan melalui konsep Catur Darma serta beberapa konsep lainnya yang telah disebutkan sebelumnya.

Pengintegrasian sains dengan nilai-nilai keagamaan bertujuan menghasilkan komunitas terdidik berintegritas dan bermoral. Tawaran ini secara prinsip melekat dengan perguruan tinggi agama, dalam konteks Kota Kendari direpresentasikan oleh kehadiran STAIN (Sekolah Tinggi Agama Islam Negeri). Namun, dalam kurun waktu 2000an, lembaga pendidikan tersebut tidak pernah sepi dari konflik internal sehingga melahirkan riak berkepanjangan. Menurut Abdullah, realitas tersebut tidak dapat dipungkiri menghadirkan kerinduan masyarakat untuk mendapatkan menu pendidikan dari lembaga yang relatif aman dari konflik. Peluang tersebut kemudian direspon secara bijak oleh elemen Muhammadiyah dengan menghadirkan UMK. Agar kehadiran lembaga tersebut direspon secara lebih positif, menurut Abdullah, UMK menghadirkan tawaran pengelolaan kelembagaan yang 
disebutnya dengan konsep ABCD serta membuka satuan program studi yang pada saat itu banyak diminati oleh masyarakat, yaitu Program Studi Pendidikan Guru Taman Kanak-Kanak. Tawaran-tawaran tersebut dikemas dan diwartakan secara baik sehingga akhirnya lembaga ini menjadi salah satu pilihan terpercaya oleh masyarakat. Model sosialisasi dan pemasaran yang dilakukan oleh UMK juga dilakukan di UM Buton. Menurut Zubair, besarnya minat masyarakat untuk mencoba keberuntungan pada program pendidikan guru SD direspon oleh elemen Muhammadiyah dengan menawarkan pembukaan program studi PGSD di UM Buton. Tawaran yang dikemas dengan sosialisasi gencar, membuahkan hasil signifikan.

Hasil pemaparan di atas menunjukkan secara jelas bahwa baik Abdullah maupun Zubair dkk. telah memperkuat landasan konseptual pendirian dua PTM tersebut dengan melakukan framing atas realitas sosial atau harapan masyarakat yang belum tertampung dan mendapatkan kesempatan melanjutkan pendidikan pada jalur sesuai keinginannya. Kehadiran sejumlah mahasiswa yang kemudian menjadikan kedua lembaga tersebut dapat bertahan di tengah arus dinamika persaingan ketat antara lembaga, secara teoretis menunjukkan keberhasilan framing yang dilakukan. Hal ini sejalan dengan yang disebutkan oleh Benford dan Snow (2000) bahwa framing dihadirkan oleh pengolah gerakan agar gagasan atau bahkan ideologi yang diusung oleh sebuah gerakan mendapat dukungan. Melalui framing juga dibentuk sebuah gerakan melabeli pengalaman-pengalaman yang akan dijadikan sebuah guideline dalam bertindak (Benford \& Snow, 2000; Snow dkk., 2004).

Secara umum, konteks yang ingin dibangun oleh penggagas UM Buton dan UMK dengan melakukan framing atas sejumlah gagasan tersebut bertujuan memberikan pemahaman mengenai situasi dan kondisi problematik, yang membutuhkan solusi sebagai jawaban sekaligus perubahan. Pada fase ini, terlihat upaya pegiat Muhammadiyah untuk mengartikulasikan masalah dan penanggungjawab. Dalam tahapan ini, aktor-aktor Muhammadiyah mencoba mendefinisikan permasalahan apa saja yang menjadi isu utama yang mendorong mereka menginginkan adanya perubahan. Permasalahan yang membuat sejumlah lulusan SLTA tidak dapat melanjutkan pendidikannya menuntut tanggungjawab semua pihak. Kondisi inilah yang berhasil membangun semangat orang-orang Muhammdiyah untuk lebih giat membuat sesuatu yang bermanfaat bagi sesama.

Realitas sosial sebagaimana yang tercermin dalam latar masalah, tidak dibiarkan beku dalam angan-angan orang Muhammadiyah. Bagi orang Muhammadiyah, berselancar membangun wacana hanyalah merupakan tahapan yang dalam teori framing yang disebut dengan diagnose. Wacana berfungsi membangun gairah bersama untuk selanjutnya melahirkan aksi nyata dalam alam realitas sebagai solusi dari peta masalah. Garis solusi yang ditempuh sangatlah sederhana, yaitu keniscayaan membangun lembaga 
pendidikan. Dengan prognostic yang dikemukan sebagai jalan keluar efektif untuk membangkitkan peluang lulusan SLTA secara berkelanjutan maka terlihat bagaimana upaya pengurus Muhammadiyah membangun motivasi warganya dan pihak luar guna merealisasikan garis solusi yang telah diukir. Pengkondisian dikemas melalui ide elegan yaitu dengan menerjemahkan ide pembangunan perguruan tinggi kedalam kalimat yang penuh makna dan bersifat motivasi (vocabularies of motive) dengan tujuan "menggoda" keterlibatan semua pihak untuk mendapatkan peserta didik.

\section{Kesimpulan}

UM Buton dan UMK adalah dua penanda eksplisit dari kegigihan elemen Muhammadiyah untuk memberi layanan pendidikan tingg kepada masyarakat Sulawesi Tenggara. Berdasarkan analisis data, ditemukan dua faktor sebagai pendorong utama gerak Muhammadiyah ketika menginisasi dan mendirikan perguruan tinggi di Sulawesi Tenggara. Pertama, faktor internal berupa kesadaran moral untuk membangun peradaban melalui jalur pendidikan. Kesadaran tersebut diikat oleh "doktrin" untuk menciptakan iklim sosial budaya berkemajuan yang disemangati oleh ruh fastabiqul khairat (berlomba membangun kebaikan). Kedua, faktor eksternal, baik yang berdimensi "pragmatis" situasional maupun pengaruh dimensi geo politik. Dorongan dimensi "pragmatis" situasional ditandai dengan upaya pemenuhan harapan masyarakat melalui pendirian program studi dengan peluang kerja yang lebih terbuka seperti PGSD dan PGTK. Sedangkan dimensi geo politik adalah memanfaatkan secara cepat dan cerdas ruang dan kesempatan yang diberi oleh pemerintah melalui pintu reformasi.

Kemampuan Muhammadiyah dalam mengelola momen, menjadi momentum hingga mewujudkan monumen infrastruktur Perguruan Tinggi Muhammadiyah, terkait erat dengan sifat kolektif kolegial dan kekuatan etos filantropi warga Muhammadiyah. Sifat dan karakter tersebut merupakan buah manis nilai fastabiqul khairat dan theology sosial al-ma'un. Nilai-nilai tersebut merupakan modal budaya yang memberi kekuatan bagi pegiat Muhammadiyah untuk berani bangkit membangun perguruan tinggi di Sulawesi Tenggara. Di sisi lain, banyaknya jaringan Perguruan Tinggi Muhammadiyah menjadikan organ ini mendapat legitimasi sosial sebagai organ handal dan terpercaya dalam tatakelola perguruan tinggi. Modal kekuatan budaya dan jaringan sosial oleh elemen pegiat Muhammadiyah dimobilisasi secara cerdas melalui framing yang elegan, sehingga akhirnya organ ini tidak hanya mampu mendirikan dan membangun, tetapi juga dapat memajukan lembaga perguruan tinggi tersebut secara berkelanjutan.

\section{Daftar Pustaka}


Ali, M. (2017). Menuju teorisasi pendidikan berkemajuan. Tajdida: Jurnal Pemikiran dan Gerakan, 15(2), 1-8.

Ali, Mohamad. (2016). Membedah tujuan pendidikan Muhammadiyah. Profetika: Jurnal Studi Islam, 17(1), 43-56. DOI: 10.23917/profetika.v17i01.2099

Amar, F. (2017). Implementasi filantropi Islam di Indonesia. AL-URBAN: Jurnal Ekonomi Syariah dan Filantropi Islam, 1(1), 1-14. DOI: 10.22236/alurban

Arfandi, H. (2016). Motif dan strategi gerakan filantropi Muhammadiyah. Jurnal Muhammadiyah Studies, 1(1), 127-155. DOI: 10.22219/jms.v1i1.11413

Benford, R. D., \& Snow, D. A. (2000). Framing processes and social movements: An overview and assessment. Annual Review of Sociology, 26, 611-639.

Binangkit, I. D., \& Siregar, D. I. (2020). Internasionalisasi dan reformasi perguruan tinggi: Studi kasus pada lembaga pendidikan tinggi Muhammadiyah. Jurnal Dinamika Manajemen Pendidikan (JDMP), 4(2), 131-138. DOI: 10.26740/jdmp.v4n2.p131-138

Binfas, M. A. M., Abdullah, M. S. Y., \& Ismail, A. M. (2014). Asal usul gerakan pendidikan Muhammadiyah di Indonesia. International Journal of the Malay World and Civilisation (IMAN), 2(2), 65-80.

Harianto, E. (2018). Empat pilar pendidikan Muhammadiyah. Prosiding Konferensi Nasional Ke-7 Asosiasi Program (23-25 Maret), 128-131.

Huda, S., \& Kusumawati, D. (2019). Muhammadiyah sebagai gerakan pendidikan. Tarlim: Jurnal Pendidikan Agama Islam, 2(2), 163-173. DOI: $10.32528 / \operatorname{tarlim} . v 2 \mathrm{i} 2.2607$

Husnaini, M. (2019). Watak Muhammadiyah: Memberi untuk negeri. Dalam A. Mu'ti, Ta'awun untuk negeri: Transformasi Al-Ma'un dalam konteks keindonesiaan (h. 87-90). Surakarta: Muhammadiyah University Press.

Koentjaraningrat. (2019). Metode-metode wawancara antropologi Indonesia. Jakarta: LIPI. 
Latief, H. (2019). Ta'awun Muhammadiyah: Rekonstruksi strategi gerakan di era disrupsi. Dalam A. Mu'ti, Ta'awun untuk negeri: Transformasi AlMa'un dalam konteks keindonesiaan (h. 191-199). Surakarta: Muhammadiyah University Press.

Miles, M. B., Huberman, A. M., \& Saldana, J. (2014). Qualitative data analysis (3rd ed.). New York: SAGE.

Mu'ti, A. (2019). Ta'awun untuk negeri: Transformasi Al-Ma'un dalam konteks keindonesiaan. Surakarta: Muhammadiyah University Press.

Nashir, H. (2015). Understanding the ideology of Muhammadiyah. Surakarta: Muhammadiyah University Press.

Opp, K.-D. (2009). Theories of political protest and social movements: A multidisciplinary introduction, critique, and synthesis. London: SAGE.

Peacock, J. L. (2017). Purifying the faith: The Muhammadiyah movement in Indonesian Islam. North Carolina: The University of North Carolina Press.

Rusydi, R. (2017). Peran Muhammadiyah (Konsep pendidikan, usaha-usaha di bidang pendidikan, dan tokoh). TARBAWI : Jurnal Pendidikan Agama Islam, 1(2), 139-148. DOI: 10.26618/jtw.v1i2.367

Setiawan, B. (2019). Teladan politik Muhammadiyah. Dalam A. Mu'ti, Ta'awun untuk negeri: Transformasi Al-Ma'un dalam konteks keindonesiaan (h. 87-90). Surakarta: Muhammadiyah University Press.

Snow, D. A., Soule, S. A., \& Kriesi, H. (2004). The Blackwell companion to social movements. DOI: 10.5860/choice.42-1896

Subarkah, M. A. (2017). Muhammadiyah dan amal usaha di bidang pendidikan. Rausyan Fikr: Jurnal Pemikiran dan Pencerahan, 13(2), 1124.

Usman, A. H. (2019). Hak milik atas tanah badan hukum persyarikatan Muhammadiyah. Jurnal Kepastian Hukum, 1(1), 34-42.

Wiktorowicz, Q. (2006). Anatomy of the Salafi movement. Studies in Conflict \& Terrorism, 29, 207-239. DOI: 10.1080/10576100500497004 
Zarro, M., Yunani, \& Dhita, A. N. (2020). Muhammadiyah sebagai gerakan Islam dan pendidikan. FACTUM: Jurnal Sejarah dan Pendidikan Sejarah, 9(1), 61-66. DOI: 10.17509/factum.v9i1.21503 